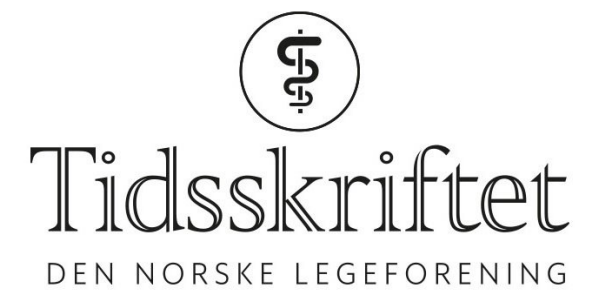

\title{
Houston, vi har en lang rekke problemer
}

TIDLIGERE I TIDSSKRIFTET

JULIE DIDRIKSEN

Tidsskriftet

Russeren Jurij Aleksejevitsj Gagarin var det første mennesket som reiste til det ytre rom i 1961. Tre år tidligere, i nr. 5/1958, trykte Tidsskriftet i spalten Excerpta en tekst om de mange problemene mennesker vil støte på i forsøket på å erobre verdensrommet (Tidsskr Nor Lægeforen 1958; 78: 200-1).

\section{Mennesker i verdensrommet?}

Nå når satellittene svirrer om vår klode, har menneskenes gamle drøm om en tur ut i verdensrommet fått ny næring. I en nøktern lederartikkel peker imidlertid British Medical Journal (Brit. Med. J. II: 1041, 1957) på at det fremdeles er en lang rekke problemer som venter på sin løsning før vi har erobret verdensrommet.

Det første gjelder størrelsen av satellitten. Major David G. Simons som nylig tilbrakte 20 timer over 30 ooo meters høyde, var lukket inne i en sylindrisk kapsel så vidt stor nok til at han kunne strekke bena. Dessuten måtte den for å være lufttett og ikke gå i filler på grunn av det lave eksterne lufttrykk veie minst $320 \mathrm{~kg}$. Så har man problemet med akselerasjonen ved take-off. Den amerikanske satellitt ventet man ville forlate jorden med en akselerasjon på bare 2,4 m/sekund (1/4 g), men denne ville øke etter som drivstoffet ble brukt opp, og sluttakselerasjonen av satellitten opp til sin sirklingshastighet på $8 \mathrm{~km}$ i sekundet vil gi mer g enn mennesket kan tåle i sittende stilling. I ryggleie kan det tåle $10 \mathrm{~g}$ i nesten 2 minutter og $7 \mathrm{~g}$ i litt over 10 minutter, så vår satellitt med passasjerer må ha en diameter som iallfall er så lang som passasjerene, og det betyr mer luftmotstand under take-off og mer drivstoff for å overvinne den.

De medisinske problemer som vil melde seg når mennesket kommer ut i verdensrommet, avhenger av definisjonen av «rommet». Der er en interplanetær luft, hvis beregnede tetthet er omkring ett vannstoffatom pr. $\mathrm{cm}^{3}$, og slutten av atmosfæren går nesten umerkelig over i den, så det er vanskelig å si hvor det ene slutter og det andre begynner. Over $15000 \mathrm{~m}$ høyde er lungene ikke i stand til å oppta surstoff fra atmosfæren fordi trykket i denne høyde $(87 \mathrm{~mm} \mathrm{Hg})$ er like trykket av vanndampen og $\mathrm{CO}_{2}$ i alveolene. Over 19 ooo $\mathrm{m}$ er atmosfæretrykket bare $47 \mathrm{~mm} \mathrm{Hg}$, og legemsvæskene er på kokepunktet, som de også vil være i «det tomme rom».

Over 24 ooo m blir trykk-kabin, slik den nå brukes i større fly, umulig på grunn av den sterke varmeutvikling ved den nødvendige kompresjon av luft fra utsiden; dessuten er der i 
denne høyde nok ozon i luften til å være giftig. Det blir nødvendig med en hermetisk lukket kabin, og den reisende må ha med seg nok surstoff for reisen, sammen med et kullsyre- og vanndamp-resorberende middel. Over $37 \mathrm{~km}$ høyde begynner den kosmiske stråling å gjøre seg fullt gjeldende. Over $45 \mathrm{~km}$ høyde blir det nødvendig å beskytte seg omhyggelig mot solens ultrafiolette stråler, og over $120 \mathrm{~km}$ høyde er der ikke nok friksjon i atmosfæren til å brenne opp meteorene, slik at disse kan gjennomhulle kabinen og redusere trykket i den til «romforhold».

Meteorer er av alle størrelser, fra mindre planeter til de minste støvpartikler, men det er god plass i verdensrommet, og de største er sjeldne nok til at man kan se bort fra kollisjonsfaren i forhold til andre farer som truer den reisende. Man har beregnet at en satellitt med radius på $50 \mathrm{~cm} \mathrm{og} 1 / 2 \mathrm{~mm}$ tykk aluminiumsvegg vil gjennomhulles av en meteor av gjennomsnittsstørrelse hver 5. dag. Derfor er det foreslått at et romskip skulle ha en ekstra vegg, som sto noe utenfor hovedveggen, for å ta av for disse kollisjoner. Men hva hvis kabinen likevel gjennomhulles? Eksperimenter har vist at hvis lufttrykket avtar til null på et øyeblikk, vil man ha bare 15 sekunder til rekompresjon antagelig i trykkdrakt. Major Simons har under sin ballongoppstigning en trykkdrakt som ikke var oppblåst, men som kunne blåses opp på et øyeblikks varsel; denne var imidlertid det mest ubehagelige ved hele turen.

Så har vi «vektløsheten» som vil inntre så snart rakettmotoren stoppes. Til forskjell fra høy g er det en tilstand man ikke kan imitere på jorden for noen særlig lang tid. Passasjerer i et fly kan imidlertid gjøres «vektløse» i en del minutter hvis det flys i en parabellignende bane like den en stein får når den kastes, og bruker akkurat så meget motorkraft at luftmotstanden overvinnes. Gerathewohl (Astronautica acta 1:32, 1955) som foretok et eksperiment med 16 mennesker på denne måte, fant at 8 av dem likte det, 3 var upåvirket av fors $\varnothing$ ket og 5 ble luftsyke.

Ross (Bull. Brit. Interplanetary Soc. 1: 49, 1946) beregnet at hver passasjer i et romskip trenger $2,7 \mathrm{~kg}$ pr. dag av mat, vann og surstoff, så det ville ikke bli så meget for en reise til månen og tilbake, som vil ta en god uke. For lengre reiser, som til Mars, som vil ta over 2 år, utarbeidet Bowman (J. Brit. Interplanetary Soc. 12:159, 1953) et skjema for å ta med planter, helst encellete alger, for å absorbere kullsyre, gi fra seg surstoff og sørge for næring, og således danne et lukket system hvor romskipet ble omdannet til en miniatyrkopi av selve jorden. En persons totalbehov ville da bli $11 \mathrm{~kg}$ alger i $200 \mathrm{l}$ vann. Algene kunne fores med passasjerenes ekskrementer, og, hevder Bowman, de måtte kunne fjerne alle spor av sitt måltid på 24 timer og så være ferdig til å spises selv. Denne utregning kan være teknisk korrekt, men ikke desto mindre lyder det en god del verre enn å drikke sitt eget badevann.

Til slutt kommer problemet med å komme tilbake til jorden i livet. Dette er virkelig litt av et problem, for en hvilken som helst ting som suser inn i atmosfæren med en fart på $8 \mathrm{~km} \mathrm{i}$ sekundet eller mer, vil gå opp i røyk hvis ikke noe gjøres for å hindre det. Vinger vil kunne være til noe hjelp, og aerodynamikerne har gitt seg i kast med problemet å få spredd varmen ved utstråling og bortledning fra vingenes forkant. Ikke meget varme kan ledes inn i romskipet, skjønt mennesket kan tåle en lufttemperatur på $90^{\circ} \mathrm{i} 40$ minutter og $115^{\circ} \mathrm{i}$ 20 minutter når det er lett kledd og i ro. Det foreligger så mange forslag til løsning av dette problem at vi kan anta, som når der foreligger mange behandlingsforslag ved en sykdom, at ingen av dem kan være noe særlig gode.

Publisert: 19. mars 2019. Tidsskr Nor Legeforen. DOI: 10.4045/tidsskr.18.0954

(C) Tidsskrift for Den norske legeforening 2020. Lastet ned fra tidsskriftet.no 